\title{
WILLIAM SHAKESPEARE IN COMMUNIST ROMANIA: FREEDOM AND LIMITATION IN ROMANIAN EDITIONS
}

\section{Iulia Andreea Milică}

During the communist regime in Romania, culture was systematically subdued to propagandistic interests, and many writers, Romanian and foreign, were submitted to the severe rules of communist censorship, or even forbidden. Nevertheless, William Shakespeare was not among these so-called "uncomfortable" writers. His immense popularity, not only in the history of world literature but also in Romania long before the communist period, with translations and theatrical performances dating back to the nineteenth century, made Shakespeare one of those writers whose fame could be used, and, sometimes, abused by the political regime. His plays often led to interpretative excesses, elements of his biography, characters or themes in his works being connected to the interests of the regime, and used to point out features favorable to the propagandistic agenda. Among such traits, the most often used were the avidity for power of the nobility, the cruelty and violence dominating the royal courts, the greedy bourgeoisie and the oppressed people with their profound spirituality, or a focus on Shakespeare's humble origins. Such connections between the Bard's life and works and the communist regime were established mainly in prefaces and introductory studies to editions of plays, as they were believed to be more efficient in reaching the reading public than critical studies or critical collections that circulated mostly among specialists. An analysis of such introductions and of some other paratextual productions (notes, bibliographies, chronological tables, postfaces) offers a perspective on the different stages of literary studies in Romanian communist history and helps us establish the level of interference of politics in cultural productions as well as the stages in the reception of Shakespeare in Romania between 1947 and 1989. 


\section{Paratext: theoretical preliminaries}

Though literary productions have received a large amount of attention from critics, the examination of paratextual strategies has not been considered equally important to that of literary analysis. However, the investigation of the different elements that form the paratext has, recently, grown in significance, especially due to the research of Gerard Genette.

The necessity of organizing the layout of the text to be published became apparent with the introduction of the printing press. The passage from the manuscript to the printed book meant not only an immense progress in the circulation of knowledge and the affordability of books, but also an important change in the visual organization of the material to be printed. Printers and editors choose to organize the material they received for publication by appealing to various strategies: titles and title pages, tables of contents, indices and commentaries separated from the main text (Janssen 2005, p. 10). Frans A. Jenssen regards all these elements as contributions to the clarity of the text and stresses the growing interest of the publishers in attracting their readers, helping them "navigate" with ease through the book and guiding their reading.

What is the paratext? The first and foremost function of the paratext is to accompany another text, in spite of the very different and hybrid forms that it may take. The paratext, therefore, presents another text; it frames, isolates, introduces, interrupts and closes the text that it accompanies (Hallyn 1995, p. 202). So, the paratextual elements do not have an independent existence, their life being conditioned by the text that they accompany. According to Gerard Genette, the paratext comprises all the productions that "surround" and "extend" the text, "precisely in order to present it, in the usual sense of this verb but also in the strongest sense: to make present, to ensure the text's presence in the world, its 'reception' and consumption in the form (nowadays, at least) of a book," (1997, p.1). He further suggests that "for us, accordingly, the paratext is what enables a text to become a book and to be offered as such to its readers and, more generally, to the public" (p. 1). Therefore, all these definitions of the paratext converge towards a common opinion: the importance of the literary production that becomes a book and is meant to appeal to a reading public from its title page (with the title and the name of the author), to all the other 
elements (that may or may not appear in a specific edition): prefaces, notes, illustrations, publisher's notices, etc.

However, paratextual productions are of very diverse forms and they fulfill different functions. F. Hallyn, for instance, suggests that some forms of the paratext may overstep their primary function of simply accompanying another text, becoming more complex (1995, p. 203), and, in this case, they may even receive a certain autonomy with respect to the central text. He refers, here, primarily to prefaces. However, there are more such paratextual elements whose function is to offer explanations, arguments, general or specific information, or critical insight, and these include, together with the prefaces, introductions, notes, afterwords, postfaces, etc.. These are the elements that we will take into consideration in the present study, as they provide a dual understanding: a) of the literary text, which is the reason of being of all these productions, and b) of the exterior world: the context that allowed the publication of the text, the conditions of publication, the manner in which the text is seen in a specific moment in time and, especially, the reader; in other words, the "inside" and the "outside" of the book.

Gerard Genette compares the preface with a "vestibule," a place of passage and "transition" establishing the relationship between the text and the world, "a zone without any hard and fast boundary on either the inward side (turned toward the text) or the outward side (turned toward the world's discourse about the text)" (Genette 1997, p. 2). It is not only a borderline zone, but also one of "transaction": "a privileged place of a pragmatics and a strategy, of an influence on the public, an influence that - whether well or poorly understood and achieved - is at the service of a better reception for the text and a more pertinent reading of it (more pertinent, of course, in the eyes of the author and his allies)" (ibid., p.2).

These paratextual productions naturally point to an important aspect to be considered in the publication of a book: namely the reader of the text who becomes the "addressee" of the paratext. If some of the paratextual productions may appeal to "undifferentiated" readers (such as the title, the name of the author, etc.), others, like the preface, address directly the specific readers of the text (Stancu 2006, p. 72). Genette comments on the importance of the reader - addressee of the paratext, and makes the distinction between the explanatory types of paratext and the other forms, considering that "the reader of the 
preface already necessarily has the book", since these types of texts (in comparison to the most obvious types of paratext, such as titles, contents, illustrations) will not easily be read in a bookshop by a hesitating buyer (1997, p. 194). Moreover, "its message postulates that its reader is poised for an imminent reading of the text (or, in the case of the postface, has just concluded a reading), without which its preparatory or retrospective comments would be largely meaningless and, naturally, useless" (ibid., p. 194). The preface, therefore, becomes an important element in the readers' reception and understanding of a given text and it fulfills a complex role, that of connecting and adapting, despite the possible incongruences, the interior (esthetic) dimension of the text, that involves the "ideal" reader, to the exterior (socio-historic) dimension, based on the reception of the literary text as "artifact", in a specific context of reception (Stancu 2006, 75).

In our more specific context of reception, the preface for an edition of Shakespeare's plays, for instance, is differently written for nineteenth century readers and for twentieth, or twenty-first century readers, for an English-speaking audience or for a Romanian-speaking audience. Similarly, the socio-politic environment is supposed to influence the data included in the paratextual productions starting from the premise that it cannot (or should not) tamper with the literary text itself.

The function of mediation and adaptation of the text to the readers becomes even more important in the case of prefaces to translations of literary works, where the effort of the preface writer is threefold, in the sense that he/she must refer to the text as such, to the context of the publication of the specific text, as well as to the problems that naturally arise in the process of translation and adaptation of a text from a language to the other. In such a case, the focus and the types of explanations given in the preface are different. Thus, seen in this light, the preface writer becomes an important participant in this complex process involving the creation, production, publication and reception of literature.

An additional function of the prefaces becomes evident in Gerard Genette's definition: the prefaces define, explain, explore, inform, and recommend. This last function identified by Gerard Genette is implicit "because the mere presence of this type of preface [allographic] is in itself a recommendation" (1997, p. 268), and, in most cases, the reputation of the author of the preface may be of utter importance in recommending a text (ibid., p. 268), of creating credibility for the specific published edition. 
In the case of the Romanian prefaces to Shakespeare's plays that we envisage in our survey (those published between 1947 and 1989), the authors who wrote prefaces for the various editions of the plays are well-established personalities in the literary and academic circles, translators, writers or university professors. Some prefaces or notes are clearly addressed to a more sophisticated readership while others aim at recommending the book to the general public.

Nevertheless, we noticed a general tendency towards a "literary intellectualized presentation" rather than a "popular interpretation of the plays" (Chesnoiu 2006, p. 32), through which Shakespeare is transformed into a cultural icon and the idea that his works are "splendid prefigurations" of the regime's "Socialist-humanist ideals" is largely promoted (ibid., p. 32).

In conclusion, one of the aims of the prefaces we envisage in the present study was to create a bridge between Shakespeare's plays and the ideals that the system wanted to transmit. The establishment wanted Shakespeare to become a support for the doctrine of the communist regime (in Romania but also in other communist countries), whereas, for the intellectuals, these translations were part of the fewer and fewer possibilities to come into contact with foreign cultures. In this light, the preface becomes the space of transaction and negotiation between, on the one hand, the importance of publishing translations from the great world authors and transmitting, through prefaces, notes and postfaces, information about the author and his age and pertinent critical analyses of the texts and, on the other hand, the political pressure to connect Shakespeare to the current ideologies and sociopolitical context in order to suggest his importance for the promotion of the communist ideals. In many cases, the acceptance of a book for publication depended on the skill of the

preface writer to introduce the text as an important asset in the education of the young communists while also managing to inform the readers and to connect them to the great world culture.

\section{Shakespeare in Communist Romania}

Like many other aspects of the cultural life, literature and literary criticism were areas heavily influenced by the change of political regime, and they were subordinated to the interests of the newly instituted communist power. That was the reason why, after a period 
of cultural flourishing that started at the end of the nineteenth century and lasted till the Second World War, there was a period of decline which coincided with the beginning of communist rule, and during which fewer books from world literature were allowed on the reading market.

The first Romanian translations from Shakespeare date from the middle of the nineteenth century: Hamlet in 1840, Julius Caesar in 1847, Othello and Romeo and Juliet in 1848. The number of translations increased towards the end of the century, coinciding with a growth in the awareness of creating a sense of national worth through the attempt to connect Romanians to the world cultural heritage by means of translations from classic authors. Translating, therefore, from the great world writers, was seen not only as a means of enlightening the population by introducing Romanian readers to world culture, but also as a path towards refining the national literary language.

Documents suggest that Romanian theater audiences were already familiar with Shakespeare's plays since the end of the eighteenth and the beginning of the nineteenth century through theatrical performances of companies that toured Transylvania, some reaching as far as Bucharest. However, most translations for the stage as well as some of the earliest translations of plays came through French and German channels (Streinu 1965, p. 45), and not directly from the original text.

The period between the two World Wars is characterized by development at all levels: economic, social and cultural. Following the Great Union of all Romanian regions in 1918, and marked by economic and political stability, Romanians were, maybe more than ever, in search of a more coherent cultural identity. The translations from Shakespeare, especially in the 1920s and the 1930s, but also at the beginning of the 1940s are an important sign of the cultural effervescence of those years which will fade with the arrival of the communist regime.

In 1944, Romania, formerly allied with Germany, sides with the Russian army, opening the path towards the imposition of a communist form of government which will completely take over the political scene in 1947, with the abdication of King Mihai I. From that moment till the fall of communism in December 1989, culture will be subdued to and controlled by politics. Though the degree of involvement of politics in literature is more visible in the analysis of Romanian literature produced and published in that period, an 
outlook on the translations of foreign authors and also on the prefaces or studies accompanying such translations is a good indication of the degree of censorship or freedom translators and critics had in different periods of communist Romania.

At the beginning of the communist regime in Romania, culture was not a priority unless it served the consolidation of communist faith and so, the literary productions of the time were based on themes and topics appealing to the communist cause (Negrici 2003, p. 19). It was obvious that Western culture was considered dangerous and the translations published at that time were mainly from Russian and Soviet authors. As far as Shakespeare was concerned, from 1947 until the middle of the fifties when the communist regime in Romania was already consolidated there is only one translation: Hamlet in 1848, transposed in prose by Maria Banus and Vera Calin.

After 1956, however, the number of translations increased, indicating a slight degree of relaxation of political control determined, on the one hand, by the fact that the political power, already fully established, felt that there was no longer any danger, and, on the other, by Stalin's death in 1953. Though it was not freedom proper, there was a change in the attitude towards literature in the sense that ideological excesses were slightly diminished, marginalized authors were brought back into the limelight, masterpieces of world literature were published again and new authors were translated (Negrici 2003, p.42). Nevertheless, the degree of censorship was still rather oppressive, and this was visible especially in the introductory studies accompanying these translations. Though such studies were of great values for readers, familiarizing them with the specific writer, his/her work and the cultural context in which the text was written, they were still subdued to the rigors of the communist ideology. In their prefaces, writers had to create a connection between the prefaced text and the communist ideology in order to facilitate the publication of the book presented that appeared as a means of educating the communist reader.

This situation changes after April 1964, which marks a rather abrupt break from Russian control and the reconsideration of Romania's political and economic interests leading to the intensification of the relationships with the Western states. On the literary scene, new writers who do not politicize their writings are allowed to publish their works. Furthermore, Romanian literary criticism becomes more and more influential on publishing policies and on the formation of public taste. This does not mean that propagandistic 
literature disappeared. On the contrary, it still proliferated but more implicit and counterbalanced by a literature that was directed towards normality tending to distance itself from propaganda and ideology (Negrici 2003, p.155). It was, therefore, a prolific period for literature and criticism and as far as Shakespeare studies are concerned, this is a rich period, with numerous translations, some published in critical editions, others containing valuable prefaces and notes.

After 1971, and especially in the 1980s, the situation changes again for the worst. Nicolae Ceausescu consolidates his power and develops his personal cult, leading to new restrictions and political impositions: numerous books belonging to world literature are withdrawn from the market or could no longer be published, whereas the Romanian younger generation of writers, who had enjoyed freedom of writing in the previous period could publish only in collective volumes. These are the years of impressive televised shows, with parades, dances or music, all dedicated to the glorification of the leader of the nation.

The eighties, in the case of Shakespeare translations in Romania, were years of synthesis, in the sense that, in 1981, the project of the re-publication of the complete works of William Shakespeare is started, with seven volumes published, in hard-cover editions, till 1989 (more volumes were printed after 1989), as well as three volumes containing Shakespeare's comedies. These publications are accompanied by comprehensive introductory studies and notes for expert readers, becoming, in that period, important work tools for students of literature.

\section{Prefaces for Shakespeare Editions in Communist Romania: Case Studies}

For this particular study, we have chosen for analysis five introductory studies, taking us on a journey through the changing rigors of Romanian criticism and political intervention in cultural productions, from 1962 to 1982 . We have studied how the constrictions of propaganda are counterbalanced by refined case studies.

Though there are inherent differences among the various prefaces, given by the fact that they introduce different plays (the analysis of which will not be the purpose of our study), it is interesting to notice how the writers of the prefaces subtly adapt their texts according to different target readers and compelled by the manner of publication of a 
specific edition or the type of collection. These prefaces always contain common elements: the life and work of Shakespeare as well as the historical and cultural context of the writing of the plays, the different editions of Shakespeare's works, Shakespeare's critics and Romanian editions, general considerations regarding themes, motives, style, etc. The differences among prefaces arise mainly from the political context of the publication of a specific edition or translation, the type of book (elegant edition, hard-cover or paper cover), the type of collection and, very importantly, the personality of the preface writer, whether he/she is also the translator of the prefaced text or not, a writer/poet or critic, all these elements contributing to different end result.

The analysis of the common elements among the prefaces helps us highlight with more accuracy the transformations occurring in the Romanian political climate that influenced the manner in which these introductory studies had to be conceived by their authors. It is evident that the prefaces written in the 1960s, especially before 1964, tend to ideologize the content more, trying to create connections between Shakespeare and the propagandistic interests of the regime. In the seventies, these propagandistic tendencies are less visible and in the 1982 introductory study to Complete Works, they disappear almost completely.

The two prefaces written to editions before 1964, namely Zoe DumitrescuBusulenga's preface for the 1962 translation of Hamlet and Romeo and Juliet, and Mihnea Gheorghiu's preface for the 1963 edition of King Lear definitely contain more propagandistic elements than the 1965 edition of Hamlet, with an introductory study, notes and translation by Vladimir Streinu.

\section{Preface to Hamlet and Romeo and Juliet by Zoe Dumitrescu-Busulenga}

The edition of Shakespeare to which Zoe Dumitrescu- Busulenga ${ }^{1}$ writes the preface was published in a famous Romanian collection entitled Biblioteca pentru toti (A Library for All), initiated at the end of the nineteenth century, and published, in time, by different printing presses. Traditionally, it was a small format and low price book, containing titles of important world writers destined to the general public. The preface,

\footnotetext{
${ }^{1}$ Zoe Dumitrescu-Busulenga (1920-2006) was a professor of comparative literature, important essayist and literary critic who had also other important responsibilities as manager of various cultural institutions. She was a remarkable presence in the cultural context of the communist years.
} 
therefore, had to be adapted to this public to familiarize them with general considerations about Shakespeare and his work.

This introductory study attests to the erudition of its author and of her desire to offer as much valuable information as possible in a very small space (25 small-format pages). She presents William Shakespeare's life in the larger context of the social and cultural transformations of his period and introduces his work in relation to other writings and writers of his time. Dumitrescu-Busulenga comments on the genres, themes and types of characters in Shakespeare only after she connects them to the literary tradition that influenced his writings and then pointing out how he improved these traditional forms.

The study is divided into two clear parts: the introductory section presenting generalities about Shakespeare's life and work and the analytical part in which each of the two plays included in the volume is extensively analyzed.

The section dedicated to Shakespeare's life, a compulsory element in all these introductory studies, does not list specific biographical data, tending, rather, to blend his life and creation to the historical and cultural context that, according to the preface writer, influenced his views. Thus, according to the preface, Shakespeare's world is marked by the pressure of great turmoil and transformation, influenced by the great geographical discoveries that opened the perspective of the people to a much wider world than they had known and to a new sense of adventure. In this context, the rise of the middle-class with a new mentality clashes against an old nobility dominated by greed, vanity and corruption and populating the court of an arbitrary, cruel and capricious queen.

The propagandistic element is visible mostly in this particular section, in the critique of the upper classes, the nobility and the bourgeoisie. The latter is characterized by contradictions between the material and the spiritual, between the aspiration towards high ideals, discoveries, freedom of thought and action and the typically British practical spirit that keeps them firmly grounded, slave to their business and to the pleasures of the body (Dumitrescu-Busulenga 1962, p. v-vi). These characteristics, the preface writer further states, in accordance to the communist theses, are typical of the ancestors of the modern Anglo-Saxon capitalists (p. vi). These assertions remain in keeping with the communist mentality, since, in the period of the fifties and the beginning of the sixties, the declared enemy of the newly instated regime was the class enemy: the greedy capitalist, too painful 
and close reminder of a "decadent" past. The Romanian literary creation of the period was likewise dominated by these stereotypes: hatred of the Anglo-American imperialists, the infamous capitalists and the rotten bourgeoisie (Negrici 2003, p. 19). In this historical context, the preface writer needs to present Shakespeare as a man of humble origins, like Epictet and Villon, minds of genius arising from humble origins (Dumitrescu-Busulenga 1962, p. iv). She continues arguing that Shakespeare's works received little attention during Queen Elizabeth's life, and he was writing on royal command, and so he underwent restrictions and interdictions in his creation, just as the young communist had to endure persecutions until the imposition of a right form of government.

The second section of the preface is much less indebted to propagandistic elements. The introductory part fulfilled the purpose of the preface, that of linking the "inside", the content of the text, with the "outside", the culture in which the text was translated and published. Therefore, it was meant to create the connections between William Shakespeare and the ideological interests of the regime and it underlined the importance of such writings in the education of the people, suggesting that they are not harmful for the ideals of the established power. Thus, the analytical part remains fairly free of such interventions. The comments that the Shakespearian anti-monarchic critique is visible in Hamlet's thoughts about his stepfather and in Polonius' portrayal as a courtier grown old in evil deeds, talkative and sly, totally subdued to his master in order to enjoy favors from him (Dumitrescu-Busulenga 1962, p.xxiv-xxv) are some of the very few remarks with an implicit ideological turn in the criticism of the royalty and nobility. Otherwise, the preface writer, having compromised, to a certain extent, the first part, has, in this way, the freedom to write a well-documented study with pertinent text analyses.

\section{Preface to King Lear by Mihnea Gheorghiu}

The second preface chosen for analysis is Mihnea Gheorghiu's ${ }^{2}$ for his own translation of King Lear, 1963. The book was published at Editura Tineretului in the collection Biblioteca Scolarului (The Student's Library), containing translations from

\footnotetext{
${ }^{2}$ MihneaGheorghiu (1919 - 2011), member of the Romanian Academy, was a poet and fiction writer, essayist, playwright and writer of film scripts, professor of universal literature and translator mainly of Shakespeare, Robert Burns, Walt Whitman and C. Dickens, with studies in letters and philosophy. He was also the chief editor of important literary magazines.
} 
classics, editions of Romanian writers, especially those studied in school or considered important for the general cultural formation of the students, volumes of fairytales, historical legends, etc. Just as in the previous case, these books were destined to a larger, less specialized public. Taking into account the avowed purpose of the communist regime to instruct the wide masses, emphasizing, however, that it was to be an instruction in the communist ideals, it is safe to assert that this type of book was more subdued to ideological rigors since it was destined to an un-initiated public who could be molded according to the regime's needs.

The tone and style of this preface differs from the previous one as it renders the information in a much simpler, straightforward way. Largely, the structure is the same: a first section dedicated to Shakespeare's life and work and another one analyzing the play in detail. However, the choice of the information to be presented is totally different. If in the previously analyzed preface, Zoe Dumitrescu-Busulenga prefers to reduce the number of precise biographical events and focus more on the historical and cultural context, Mihnea Gheorghiu gives ample details on Shakespeare's life and the stages of his creation, combining them with cultural or historical data only inasmuch as they are useful for a broader understanding of the creative effort. The way in which these historical details are presented bears a resemblance with the previous preface suggesting a general ideological trend pervading the literary works of the 1950s and the 1960s. Thus, Shakespeare is viewed, again, as the product of the humble and exploited masses. He was forced to give up his education in order to work hard to earn his living because of the political and religious persecutions which his family had to endure from the local landlord (Gheorghiu 1963, p. 6). Queen Elizabeth is the same fierce and avaricious queen who favors the rise of the bourgeoisie only to form an alliance with the nobility in order to consolidate her power (p. 9). Mihnea Gheorghiu goes on commenting that Shakespeare's work was influenced by the political transformations of his time. He starts his career in an optimistic, lively, patriotic vein that fades away towards the end of his life, partly by witnessing the reign of Elizabeth, and partly by noticing the return of the nobility to power under James I, which led to the oppression of the masses who had to endure the selfishness of their rulers (p. 9). Thus, the preface writer highlights Shakespeare's care for and interest in the simple people, their dreams and ideals visible in tragedies as well as in comedies. Shakespeare's histories reveal 
the people's desire for peace and prosperity and their fight against feudal anarchy in the creation of a centralized state, based on laws that protect the rights and dignity of the simple and the oppressed (p. 10).

In a similar manner, many of the plays are briefly presented by pointing out elements that connect them with communist ideals. For instance, the love in Romeo and Juliet, is represented against the background of the feudal family with its obsolete ideas, whereas, in The Merchant of Venice, human values triumph against the bourgeois love of gold. All these comments are examples of the intervention of communist ideology in the writing of the preface, Shakespeare becoming the protector and the voice of the simple people whereas the upper classes are vilified and presented only in a negative light.

These rather exaggerated ideological accents attest to the attempt to publish masterpieces from world literature by reconciling them with the requirements of the political propaganda. It had to be clear for the representatives of the censorship (those who allowed a book for publication) that these writings were in keeping with the ideals promoted by the regime and did not help Romanian readers form any anti-communist opinions. Beside the valuable text analyses, there was the danger of historical distortion, a sad reality in the communist period in which history was often distorted or rewritten, to comply with the ideological requirements of the time. The focus of all writings published in that period had to be on the working class, creator of material and cultural goods, according to the Marxist doctrine, oppressed by the upper classes, the bourgeoisie and the nobility. So, the Romanian reader was led to understand that the Western world was flawed and that the great minds struggled hard to create and transmit their creations.

It is, however, difficult to quantify, at this point, whether such writings did much damage to the reading public. Readers with limited historical or cultural backgrounds might have acquired a false representation of history, but those who bought and read such books had a certain degree of education and also, many of the readers of the sixties still belonged to generations educated before or during the Second World War, before the communist period.

Preface to Hamlet by Vladimir Streinu

Tradução em Revista 12, 2012/1, p. 30 
The political and cultural situation turns around after 1964, and the prefaces written after that period clearly display a change in focus. Thus, in 1965, a very beautiful edition of Hamlet is published at "Editura pentru literatura." It is a hardcover, bilingual edition, with translation, preface, introduction and notes by Vladimir Streinu ${ }^{3}$.

The main difference between this edition and the previous ones is not only the moment of publication that coincides with the beginning of a period of cultural development, but also the type of edition. The format of the book, the fact that it is a bilingual edition and the extensive paratexts suggest that the target is no longer represented by the average readers of "Biblioteca pentru toti" or "Biblioteca scolarului" editions. Here, only a more educated audience could appreciate the extensive information and comments offered by the translator and preface writer.

The introductory part is divided into a Preface and an Introduction. The Preface contains general information about the different editions of the play, the purpose of this edition and the history of Hamlet in Romania. The writer also makes comments on different translation problems. The Introduction refers more closely to the play: the sources, biographical issues that might have influenced the writing of the play and Hamlet in world criticism. In other words, Streinu separates the issues connected to the Romanian version of the play and this specific edition from the general information about Shakespeare and his work, reversing, thus, the order of the previous prefaces that start with information on Shakespeare and his time and move to the particular play presented in the volume. This focal reversal highlights the importance of Romanian translations and of Romanian critical endeavors in the context of world translations of Shakespeare and criticism.

There are several other novelties that distinguish this edition from the previous ones. Firstly, the tribute paid to his forerunners in Shakespeare translations and text analyses, since Streinu goes back to the first translations, commenting on the publications about Shakespeare before and after the change of political regime. He, thus, ignores, for the

\footnotetext{
${ }^{3}$ Vladimir Streinu (Nicolae Iordache, 1902-1970) was an important Romanian critic and writer with an extensive cultural activity. Graduating from the Faculty of Letters in Bucharest, he had an intense cultural and academic life in the period between the two World Wars. He was an editor at important literary magazines, and, as a poet, he was acquainted with famous writers of the period. He translated Proust and Shakespeare. He traveled abroad, mainly to write a PhD dissertation in France. The communist regime was not favorable to him because of his democratic and anti-communist views and he was arrested on political charges from 1959 to 1962 when he was politically rehabilitated. He became a researcher at the Institute of Literary History and Theory, Manager of Univers Publishing Press and honorary professor at the Faculty of Romanian Language and Literature.
} 
first time, the limitations artificially imposed through the intervention of politics in culture and acknowledges what happened in Romanian culture before communism. Secondly, this preface analyzes the difficulties in translation and the results he, as a translator chose, by comparing and selecting from different Romanian or foreign (German, Russian and French) translations as well as from different editions of Shakespeare. The notes will carry further such comparisons and analyses as Streinu tries to clarify the meaning of lines and words in the text by amply commenting on them. This suggests more clearly that he envisages a more specialized readership than that intended for the previously mentioned prefaces. Thirdly, the introductory study contains critical appreciations made by famous Shakespearean commentators, from earlier sources to the Romantics (Goethe, Schlegel, Coleridge), from T. S. Eliot and Papini to Harvey Grenville Baker or George Santayana. Mentioning such sources and making the reader aware of a new world of ideas and interpretations marks a change in the attitude of the political system becoming more permissive and open to foreign influences.

In spite of all these great changes in perspective, the ideological elements, however, do not completely disappear. Rather, they are inserted in such an elegant way that they do not distort, as they previously did, the information contained in the prefatory writings. Streinu manages to present historical events or episodes from Shakespeare's life free from the ideologized comments of the previous preface writers.

The first ideological comment is inserted quite late in the Preface when Streinu asserts that after the "liberation of the country," on August 23, 1944", the communist leaders considered important to culturally enlighten the masses and so, teams of translators were gathered to translate world masterpieces into Romanian (1965, p.xvi). We need to point out the fact that Streinu's comment refers strictly to the situation in Romania after the change of the political regime and does not influence at all the reception of Shakespeare or the presentation of the historical and cultural realities of the Bard's time. It serves its purpose, namely to highlight the positive influence of the communist regime for the cultural development of the country, but it does not brutally interfere or distort the material to be presented, as it was the case of the previously analyzed prefaces. The second

\footnotetext{
4 "Liberation of the country" was the term used by the communist propaganda to explain the events that occurred on August 23, 1944, with Romania siding with the Russian army after having been Germany's ally.
} 
propagandistic hint is included in the conclusions of the Preface: Streinu reiterates his previous assertion, stating that, for twenty years now (more exactly the period between 1947-1965), the communists had proven they cared for the masses, given their desire to educate the simple people and help them develop an interest in world literature. He modestly (though it sounds rather ironical) claims that this edition of Shakespeare could not have been printed outside the popular-democratic conception of Romanian literature, the author feeling proud that he could be part of this rich political orientation (p. XXII).

This conclusion of a preface that is more indebted to the Romanian culture before the Second World War (as far as Romanian translations are concerned) and to Western critical appreciations is clearly meant to divert the attention of the censorship, modestly placing this effort under the protective influence and support of the political regime. Today, this motivation sounds ironic, as it clashes rather discordantly against the elegant and refined preface. Moreover, it is written by a man whose formation and education are indebted to another historical period (the pre-communist one), and whose previous persecutions by the political regime would have given him the right measure of the damaging influence of Communism on the Romanian culture.

\section{Preface to Hamlet by Cornelia Comorovski}

This turn towards openness starting in the middle of the 1960s is more obvious in the 1970s and 1980s. Loud propagandistic considerations were less and less present in critical texts and signal a change in political orientation in the sense that, the system being fully established, there was no longer the need of educating the readers in accepting the communist values through a sustained propagandistic effort. Now, the interest was in maintaining the system by eliminating what was considered dangerous, whereas the resistance, more visible in theatrical performances, TV comical sketches or literature would make use of irony, allusions and innuendo to circumvent the attention of the censorship. In criticism, such techniques were not too efficient, but it is obvious that the writing of such texts was no longer under the pressure of political propaganda.

The 1974 edition of Hamlet published at "Editura Albatros" in the collection Lyceum, Commented Texts, with a translation by Leon Levitchi and Dan Dutescu, has a note on the edition, a preface, a chronological table, notes and bibliography by Cornelia 
Comorovski ${ }^{5}$. Though not submitted to ideological pressures, this edition is indebted to the rigors of the collection, explained in the "Note on the Edition": forced to comply with a certain book format, the editor, C. Comorovski, took out of the play a total of 1166 lines, trying, as she mentioned, to preserve the scenes that guide the reader towards a deeper understanding of the hero. The paratext is organized according to the requirements of the collection and is meant to offer study tools for students or researchers. While the previous prefaces were written in an essayistic manner, this particular study is more academic, containing numerous footnotes and references to specialized bibliography. Similarly, it contains, at the end, a list of editions of Hamlet published after 1948 (during the communist period only) and a selective bibliography, with important foreign and Romanian titles. There is also an end-section of critical opinions of famous foreign and Romanian scholars: Coleridge, H. Taine, Liviu Rebreanu, Ioan Botez, Benedetto Croce, Wilson Knight, Mark van Doren, John Masefield and Alexandru Dutu.

The ideological substratum is almost unnoticeable in this edition. The study displays an openness towards foreign criticism that was also visible in the 1965 edition, but lacking in the 1962 and 1963 editions, where the preface authors had to implicitly use critical sources without directly quoting from any Western critic. Some of the critical references are quite new in relation to the date of publication of this particular essay, testifying of the fact that Romanian academics could now benefit from a relatively easier access to foreign critical sources, other than the Russian ones, than before. The historical section is well documented, insisting on the possible influence of specific historical events on the writing of Hamlet, but the presentation of these events or characters is no longer distorted or biased, but objective and correct.

However, there is an implicit intervention and control visible at a closer look and also by comparison to prefaces written for other authors: the obligation to include, among the critical sources mentioned, Romanian critical considerations, pointing out the importance of Romanian research in the field. Thus, in the list of selective bibliography, there are ten foreign titles and nine Romanian titles, including two of the prefaces already mentioned in this study (Zoe Dumitrescu-Busulenga and Vladimir Streinu), whereas among

\footnotetext{
${ }^{5}$ Cornelia Comorovski was a lecturer of Comparative Literature at the University of Bucharest.She is known, in Romania, mainly for her studies on writers like Shakespeare, Thackeray, Proust and Appolinaire. She defected in 1977 for France.
} 
the critical opinions, there are six quotations from famous foreign scholars and three from Romanian writers or critics. There is the pressure, therefore, to place Romanian criticism on Shakespeare, which, at the time, was not well-established, consisting of very few volumes and anthologies of critical studies, a number of essays published in literary magazines and prefaces to editions of translations, on the same level with Western criticism. It signals the fact that the intervention of the regime was visible in the obligation to focus, in any type of endeavor, on Romanian sources to highlight the importance of Romanian culture. Though it is not an utterly negative element, it remains an exaggeration in the sense Romanian criticism was not comparable to the remarkable foreign studies, especially in the context of decades of forbidden contact with world literature and criticism.

\section{Preface to the Complete Works by Leon Levitchi}

The last introductory study that we envisage dates from the last decade of the communist era and opens an important endeavor: the collection of complete works of Shakespeare, translated into Romanian. The editor of this collection, also translator of many plays is Leon Levitchi ${ }^{6}$ and his introductory study included in the first volume of Complete Works is the most extensive of all the texts we analyzed. It is a very complex study containing information already present in other prefaces (Shakespeare's life, historical events, important editions, the chronology of the plays), but also elements that were new to the reader, such as controversies regarding Shakespeare, mentioning even the cryptographic efforts to decipher the Bard's life up to the claims that Shakespeare did not exist or the "Baconian heresy." There are multiple references to the historical and cultural context, covering areas from politics to society, arts, and the educational system, in the attempt to better explain the complexities of Shakespeare's works. However, there are no political distortions or propagandistic considerations, nor ideological allusions to diminish the importance of this study.

\footnotetext{
${ }^{6}$ Leon Levitchi (1918-1991) was one of the most important personalities in English studies, professor at the University of Bucharest, translator from English into Romanian and also from Romanian into English, writer of critical studies, of dictionaries and textbooks for students of English. He is also known as one of the most important specialists in Shakespeare studies in Romania, with numerous translations and critical studies, being also the editor of the series of Complete Works.
} 
Among the numerous critical references, very few in comparison to the 1974 preface belong to Romanian critics, while most are from reputed English critics, marking a change from the previous authors, whose education was mainly in comparative and world literature and whose readings of Shakespeare were more general. Levitchi, as a specialist in English studies, had access to a more specialized type of bibliography used in the analyses of themes, motives and style, anchored on numerous quotations from Shakespeare' works. In this way, this preface also marks a step forward in the establishment of English studies in Romania, Levitchi being one of its more important promoters.

There are three major points of interest that we can distinguish in Levitchi's preface. First, the general presentation, found in all the other prefaces mentioned. What is to be appreciated here is a chronology of the plays that includes the English title, the Romanian title and the first Romanian translation, an endeavor encountered only in Streinu, whereas, Comorovski mentioned, in the case of Hamlet, only the plays translated after 1948, after the communist regime came to power. It is also the first preface that mentions plays of controversial authorship like Pericles, Arden of Feversham, Sir Thomas More, Edward III, A Yorkshire Tragedy, Cardenio and The Two Noble Kinsman, and commenting on whether they are attributed to other writers or written in collaboration. Levitchi, therefore, is the first author to enlarge, for the Romanian public, the information on the Shakespearean cannon.

The second point of interest is the critical one, containing extensive comments on style, themes, motives, whereas the third direction may function as a theoretical tool for translators, referring to the importance of translations for a culture and mentioning the difficulties and controversies of the Shakespearean text that need to be solved by the translator, being, therefore, an important asset not only for Shakespeare studies, but also for translation studies.

It is difficult to find, in this text, any ideological comment or submission to political requirements. The published text demonstrates an openness towards foreign criticism without fear of presenting controversial ideas about Shakespeare that are not included in any of the prefaces previously published. Though still remaining a cultural icon, Shakespeare is presented here as a more complex personality and his life and work are not meant to serve any communist propagandistic purposes. 


\section{Concluding Remarks}

In conclusion, the prefaces to translations from the great world writers, Shakespeare in our case, offer a mirror of the path taken by Romanian literature and criticism in the years of communism, pointing, on the one hand, to the rigors imposed by the regime in the attempt to control all areas of human existence in order to stifle any form of disagreement or rebellion and, on the other, to the forms of survival of a culture, bending to the new political requirements, compromising, undermining and continuously adapting to a changing world. We have seen how the political propaganda in the 1960s required exaggerations in the presentation of historical realities to fit the ideals of the Party, and then how scholars were gradually given more liberty.

Speaking about literature in communism, Eugen Negrici mentions the fact that the literary scene was invaded by mediocre writers ready to do anything to enjoy the fruits of success that, in different historical and political circumstances, would have been denied to them. The system had efficient methods, more obvious in the fifties and sixties, more cunning in the seventies and eighties, to make people follow the rules it imposed, and even some of the great writers were caught in that net and served the regime following the philosophy 'publish or be damned.' (1999, p. 1-2). The same situation can be noticed in the academics or critics. Access to publications, to a better job (maybe even a university career) and especially to positions of management led to many compromises. Some of them had experienced the persecutions of the regime (Vladimir Streinu) and then tried to survive, others did not resist much longer and left the country (Cornelia Comorovski). While others adapting, serving the regime in a louder manner or trying to get by as elegantly as possible succeeded in doing a remarkable thing, highly appreciated by all those who lived through those years: bringing culture to the people, helping them survive a harsh and restrictive life by offering them a refuge from a grim reality.

\section{References}

CHESNOIU-MATEI, Monica. Shakespeare in the Romanian Cultural Memory.

Foreword by Arthur F. Kinney. Madison, Teaneck: Farleigh Dickinson University Press, 2006. 
COMOROVSKI, Cornelia. Preface, Chronological Table, Notes and Bibliography. In: SHAKESPEARE, William. Hamlet, print al Danemarcei. Translated by Leon Levitchi and Dan Dutescu. Bucuresti: Albatros (Lyceum: Texte comentate), 1974.

DUMITRESCU-BUSULENGA, Zoe. Preface. In: SHAKESPEARE, William. Romeo and Juliet, Hamlet. Translated by St. O. Iosif, revised by Al. Philippide (Romeo and Juliet) and Stefan Runcu (Hamlet). Bucuresti: Editura pentru literatura (Biblioteca pentru toti), 1962.

GENETTE, Gerard. Paratexts: Thresholds of Interpretation (Literature, Culture, Theory). Translated by Jane E. Lewin, foreword by Richard Mackesey. Cambridge University Press, 1997.

GHEORGHIU, Mihnea. Preface. In: SHAKESPEARE, William. Regele Lear. Translated by Mihnea Gheorghiu. Bucuresti: Editura Tineretului (Biblioteca scolarului), 1963.

HALLYN, Fernand. Aspects du Paratexte. Introduction. In: DELCROIX, Maurice; HALLYN Fernand (Eds.) Méthodes du texte. Introduction aux études littéraires. Eds. Paris, Bruxelles: De Boeck - Duculot, [1987] $6^{\mathrm{e}}$ tirage 1995.

JANSSEN, Frans A. The Rise of the Typographical Paragraph. Cognition and the Book. Typologies of Formal Organisation of Knowledge in the Printed Book of the Early Modern Period. Intersections. Yearbook for Early Modern Studies, 4 / 2004. ENENKEL, Karl A. E.; NEUBER, Wolfgang (Eds.). Leiden/Boston: Brill, 2005.

LEVITCHI, Leon D. Introductory Study, Notes on Literary History and Comments. In: SHAKESPEARE, William. Opere complete (Vol.1). Bucuresti: Univers, 1982.

NEGRICI, Eugen. Literatura romana sub comunism: Proza. Bucuresti: Editura Fundatiei PRO, 2003.

NEGRICI, Eugen. Literature and Propaganda in Communist Romania. Bucharest: The Romanian Cultural Foundation Publishing House, 1999.

STANCU, Valeriu. Paratextul. Poetica discursului liminar in comunicarea artistica. Iasi: Editura Universitatii “Alexandru Ioan Cuza”, 2006.

STREINU, Vladimir. Preface, Introduction, Notes and Comments. In: SHAKESPEARE, William. Tragedia lui Hamlet, Print de Danemarca, bilingual edition. Translated by Vladimir Streinu. Bucuresti: Editura pentru Literatura, 1965. 